\title{
Five Accessibility Challenges in Access Auditing Mosque Designs
}

\author{
Nur Amirah Abd Samad 1, Asiah Abdul Rahim 2, Ismail Said ${ }^{3}$ \\ $1 \mathrm{PhD}$ candidate, FABU, \\ Universiti Teknologi Malaysia (UTM) \\ \& Centre for Innovative Architecture and Built Environment (SErAMBI), Faculty of Engineering and Built Environment, \\ Universiti Kebangsaan Malaysia (UKM), 43600 UKM Bangi, Malaysia \\ ${ }^{2}$ Department of Architecture, Kulliyyah of Architecture and Environmental Design, \\ International Islamic University Malaysia (IIUM) \\ ${ }^{3}$ Department of Landscape Architecture, Faculty of Built Environment and Survey (FABU), \\ Universiti Teknologi Malaysia (UTM) \\ amirahsamad@ukm.edu.my, arasiah@iium.edu.my, ismailbinsaid@gmail.com \\ Tel: $012-2315857$
}

\begin{abstract}
Mosques are frequently visited because it is a place for worshipping God for devoted Muslims and its communal qualities. The lack of accessibility creates physical barriers for PwDs and the elderly and has discouraged them from joining congregational prayers. Mosque accessibility is a prolonged issue that needs mitigation hence the access challenges. Five accessibility challenges are discussed by assessing the Mosque's typical design and its facilities to its level of accessibility. Conclusively, the five access challenges reviewed in Access Auditing of mosque's cases should be the focus for renovation and upgrading to be an inclusive Mosque.
\end{abstract}

Keywords: Mosque Accessibility; Persons with Disability (PwDs); Universal Design; Access Audit.

eISSN: 2398-4287 @ 2019. The Authors. Published for AMER ABRA cE-Bs by e-International Publishing House, Ltd., UK. This is an open access article under the CC BYNC-ND license (http://creativecommons.org/licenses/by-nc-nd/4.0). Peer-review under responsibility of AMER (Association of Malaysian Environment-Behaviour Researchers), ABRA (Association of Behavioural Researchers on Asians) and cE-Bs (Centre for Environment-Behaviour Studies), Faculty of Architecture, Planning \& Surveying, Universiti Teknologi MARA, Malaysia. DOI: https://doi.org/10.21834/e-bpj.v4i12.1937

\subsection{Introduction}

The Mosque is among frequently visited building typology because of its divine place for worshipping God in congregational for devoted Muslims and its communal qualities. A Mosque is a facility that is often visited by People with Disabilities (PwDs) and elderly Muslims other than the general public, as devoted Muslims attend to perform their five daily prayers in congregation and to learn more about Islam. The lack of seamless access at Mosque creates physical barriers for PwDs and elderly, which have discouraged them from visiting mosques for congregational prayers and other related community activities. Mosque accessibility has been a prolonged issue, and it is a problem that needs mitigation between design consultants, the local authorities, and the Mosque's facilities management personnel in providing and maintaining mosque facilities for accessibility purposes.

As coined by Hussein and Yaacob (2012) and by Kaur and Tan (2018), the Malaysian Persons with Disabilities Act 2008 defines PwDs as individuals with long-term physical, mental, intellectual or sensory impairments. The definition, the PwDs, which in interaction with various everyday obstacles, may prevent their full and active participation in daily activity and the economy. Apart from the PwDs Act, The Malaysian Ministry of Women, Family and Community Development has published the 'Plan of Action for People with Disabilities 2016-2022' by outlining ten (10) strategic cores that matches ten (10) goals of the Incheon Strategy with Core Strategic 1 (Goal 3 Incheon Strategy) on increase accessibility of PwDs mobility and quality of life for a productive and inclusive community (Asiah, Azila et

eISSN: 2398-4287 @ 2019. The Authors. Published for AMER ABRA cE-Bs by e-International Publishing House, Ltd., UK. This is an open access article under the CC BYNC-ND license (http://creativecommons.org/licenses/by-nc-nd/4.0). Peer-review under responsibility of AMER (Association of Malaysian Environment-Behaviour Researchers), ABRA (Association of Behavioural Researchers on Asians) and cE-Bs (Centre for Environment-Behaviour Studies), Faculty of Architecture, Planning \& Surveying, Universiti Teknologi MARA, Malaysia. DOI: https://doi.org/10.21834/e-bpj.v4i12.1937 
al., 2015; Asiah, Nur Amirah et al., 2017; Zainol, Mohd Isa et al., 2018). Mosque accessibility will ensure full community participation, including the marginal groups of the PwDs and elderly, to be socially inclusive through public built environment.

\subsection{Aim and Objectives of the study}

This study aims to identify the common accessibility obstacles and provide recommendations or innovation design solutions to accommodate accessible design that complements within the Islamic views. The objectives are, firstly, to analyze the level of accessibility in mosques design by Access Auditing simulation method, and secondly, to investigate the common identified accessibility challenges that are typical for Mosque design and that derived from access items in the Access Audit checklist developed.

\subsection{Literature Review}

\subsection{Mosque Design; Modern and Heritage Mosque}

Mosque usually is the epicenter of the idea of an Islamic city planning, where the interconnectedness between Din (religion) and Madinah (city) reflecting supervise human activities with the notion of submissiveness. For the Muslim community, mosque is a necessity in fulfilling the preservation of five essentials of maqasid al-shari'ah of faith, self, intellect, lineage, and property, in its respective ways (Asiah, Azila, et al., 2015). According to JAKIM, Malaysian mosques classifies into five general groups, and mosques usually are the principal, state, and some private funded mosques (Asiah, Azila, et al., 2015; MS2577:2014, 2014; Utaberta, Niya et al., 2017).

Issues in modern mosque design are listed as follows; (i) the architectural identity; (ii) conceptual form and structure; (iii) the position and location of mosques; (iv) the use and function of space planning; (v) the safety and security of mosque spaces; (vi) the administration and economy; (vii) the congregation and users especially concerning women, children, PwDs, and elderly (Nangkula, Hafsah et al., 2015). Asif, Utaberta et al. (2019) has described, the potential of urban mosques in compact city, that is to adapt with its surrounding environment, considers lifestyle changes, innovative use of space, optimizing and expanding functionality by maintaining aesthetic of the original structure; regardless of activity pattern, space usage, and functional efficiency. Asiah and Nur Amirah (2014) conveyed that a provision of suggesting an accessible route for existing mosque could keep the cost of renovation to a minimum, where refurbishment categorized by essential areas that are highly accessible, examples of the parking area, entrance, prayer hall, toilets, and ablution areas as well as wayfinding. While Mahsa, Utaberta et al. (2015) suggested accessibility aspect of approach to building, the horizontal and vertical circulation and mosque facilities and amenities.

Abdul Kadir, Jamaludin et al. (2019) emphasize the issue of accessibility in heritage buildings that are important to be addressed as 'heritage' as it valued as a significant aspect for the Malaysian tourism industry. As some Mosques are enlisted as National Heritage building that were built in the 70's and 80's and holds historical significance has also been coping with the demand of providing accessibility for PwDs and elderly. Mosque typology is a priority as it is most visited and used by the public daily, whether historical or heritage and big or small usage capacity. Overcoming the difficulties faced by PwDs requires interventions to remove environmental and social barriers due to lack of access and no facilities provided (Asiah \& Nur Amirah, 2014) in various heritage building typology needed accessibility adaptation in the conservation of heritage buildings (Abdul Kadir et al., 2019).

\subsection{Community Inclusion and Mosque Accessibility}

There is a negative conception of public acceptance in Malaysian society that still exists nowadays as portrayed by Kaur and Tan (2018) that public acceptance relationship between PwDs and 'able-bodied' shows that the public still has a low acceptance of disabilities in the community. The PwDs perceive their acceptance by the public community as unsatisfactory, where the public is overly sympathetic towards them and has not given equal treatment as 'able-bodied' counterparts, are viewed negatively and possibly bullied. It was also argued previously by Hussein and Yaacob (2012) on the notion of the social model of disability was suggested throughout the Act, as defining disability as evolving. However, the PwDs Act 2008 is perceived as a charity and as a welfare basis according to the existing medical model that focuses on impairments and negative perceptions.

Concerning mosque functions, many main mosque has opened up their doors into organizing public events such as religious talks and seminars, weddings receptions, and solemnization events that requires the public' participation within the community. A mosque shall be universally designed to cater all kinds of users, including PwDs, the elderly, and children, as there are mosques that offer complementary functions such as nursery/daycare, religious school (madrasah) and bazaar (souq) for business purposes and accommodation. As elaborated by Asiah, Azila, et al. (2015), mosque institution is also devised towards providing supports for the PwDs through its activities and number of programs are among the elements assessed in increasing mosques' ratings. The importance of providing accessibility is to give the PwDs an equal opportunity for them to perform congregational prayers in respect of helping them perform their obligation as other devoted Muslims (Asiah \& Nur Amirah, 2014; Utaberta et al., 2017).

Universal Design is the basis of creating accessibility in the built environment and practically in mosque environment as many researchers (Fletcher, 2016; Heylighen, Linden et al., 2017; Kurniawan, 2010; Mahsa et al., 2015; Nur Amirah, Ismail et al., 2018a; Shah, Shar et al., 2018; Utaberta et al., 2017) has reinterpreted it within its definition of 'design of products and environments usable by all people to the greatest extent possible, without the need for adaptation or specialized design.' Several researchers within the local context, such as (Kadir \& Jamaludin, 2013; Mahsa et al., 2015), have also regarded Universal Design as a significant component for social sustainability in sustaining well-being, safety, and accessibility in encouraging participation and social interaction within a livable community. Universal Design may cater to the needs of diverse users for a lifetime. It can contribute by sustaining the built environment 
throughout life-changing event (Abdul Kadir \& Jamaludin, 2018) and can also be developed as a Corporate Social Responsibility by companies and clients by constructing for the public (Asiah, Naziaty et al., 2015).

\subsection{Methodology}

The methodology approach is qualitative that will be participatory of actual PwDs of four (4) disabilities category with interviews to identify accessibility obstacles and narrative by explanatory of checklist items (Creswell, 2012). The qualitative research design is content analysis of regulatory documents relating to Universal Design and Mosque building typology with access audit checklist to measure the level of accessibility according to technical access designs, drawings and documents (Walliman, 2011) such as PwDs Act 2008, UBBL 34A, MS1184, MS2577 and JAKIM design guidelines as previously laid out in detail by these local researchers (Hussein \& Yaacob, 2012; Kadir \& Jamaludin, 2012a; Kamarudin, Ariff et al., 2014; Kamarudin, Hashim et al., 2012; Mahsa et al., 2015; Maidin, 2012; Nur Amirah, Ismail, et al., 2018a; Nur Amirah, Ismail et al., 2018b; Yusof \& Jones, 2016). The findings analyzed within the capacity of a case study or a 'bounded system' of a specific case example of various state and heritage Mosque in Malaysia (Groat \& Wang, 2002; Merriam, 2009).

\subsection{Access Audit Method and Access Audit Checklist}

While the method of conducting Access Audit simulation is describe and physically conducted by (Asiah, Azila, et al., 2015; Asiah \& Nur Amirah, 2014; Hashim, Samikon, et al., 2012; Kadir \& Jamaludin, 2012a, 2012b; Kamarudin et al., 2012; Nur Amirah, Ja'afar et al., 2018) in particular at several case studies of state and heritage Mosques in Malaysia. This study further investigates the Mosque's level of accessibility by Access Audit by using assessment tool of Access Audit Checklist, that was initiated by referring to items in UBBL 34A and MS1184:2014 (access audit manual \& access audit checklist for buildings, 2018) and the time taken to conduct an Access Audit at one mosque. Under Mosque building typology, there were five (5) accessibility challenges discussed by assessing the Mosque's typical design and its facilities to its level of accessibility.

\subsection{Findings and Discussion}

\subsection{Access Audit simulation at Mosque Case Study}

Access Audit simulation will usually begin with an introductory meeting with the Access Auditing team that consist of expert Access Auditors, and actual PwDs of four (4) identified disability category, namely; wheelchair users; physically challenged or elderly with mobility issue; the blind and the deaf; with go-along interviews with PwDs on the aspect of access, barriers and communication issues with the management and caretakers of the Mosques.

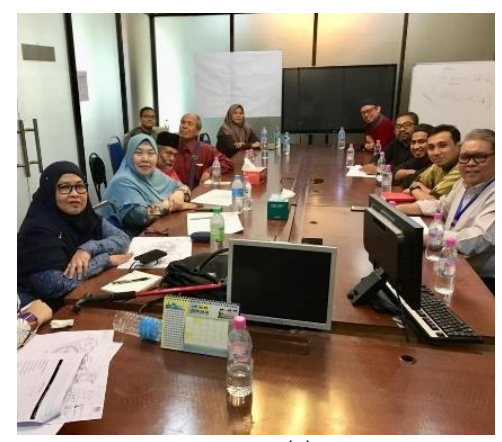

(a)

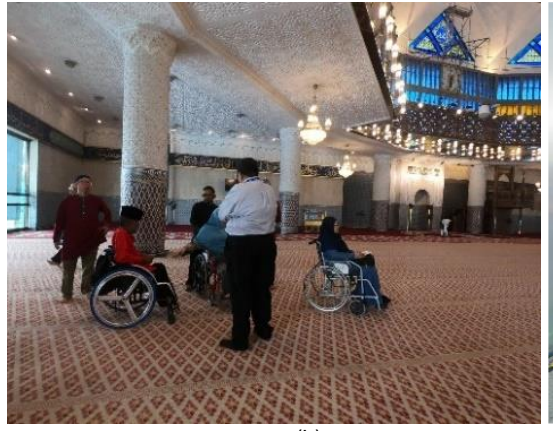

(b)

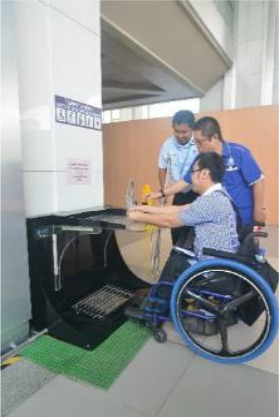

(c)

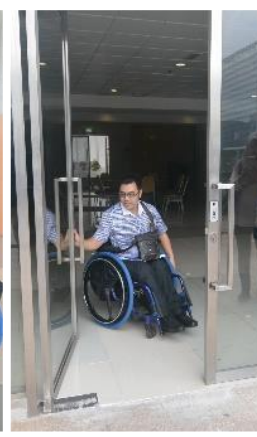

(d)

Fig. 1. (a) Introductory meeting with Mosque's management; (b) Prayer Hall visit; (c) Using the portable wudu' station; (d) Main access evaluated. (Source: Author)

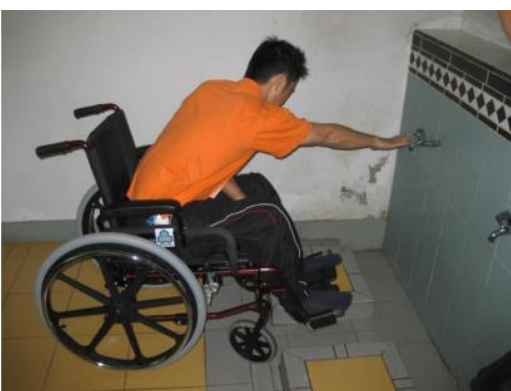

(a)

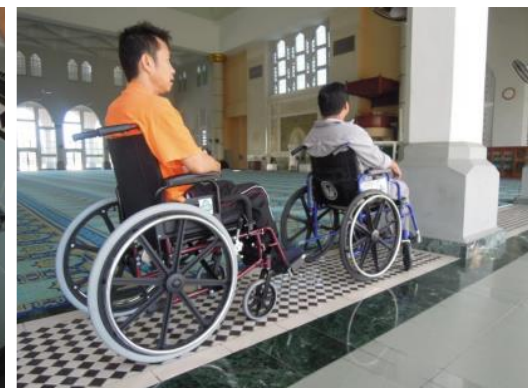

(b)

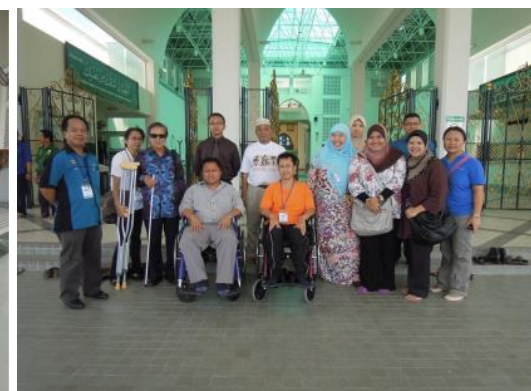

(c)

Fig. 2. (a) Testing existing wudu' area; (b) pray area for wheelchair users; (c) Access Audit expert team with PwDs. (Source: Author) 


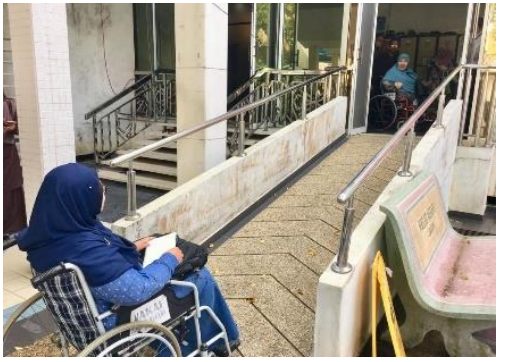

(a)

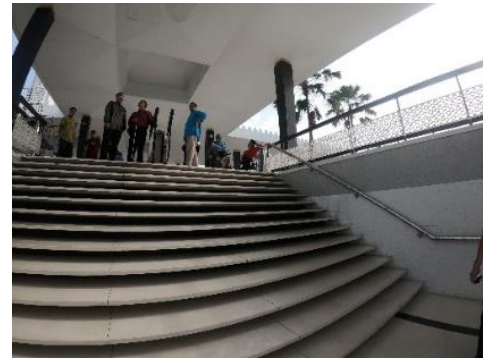

(b)

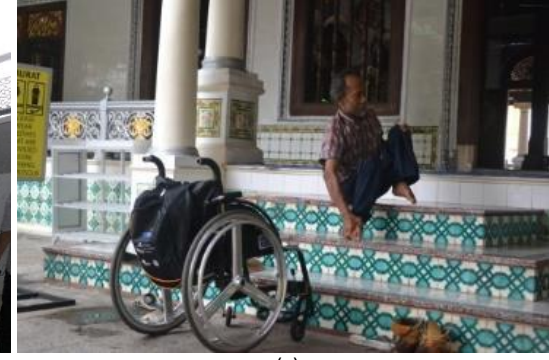

(c)

Fig. 3. (a) Testing existing ramp; (b) Inaccessible main entrance; (c) Inaccessible steps main entrance. (Source: Author)

\subsection{Identifying possible accessible route on plan}

Some mosque audited has provided the team with drawings of building plans where we can identify to create an accessibility map based on the findings from access auditing. When the AutoCAD drawings are not available from consultants, some building plans of mosque are hand-sketched, and some are diagrams of spaces to established an access route.

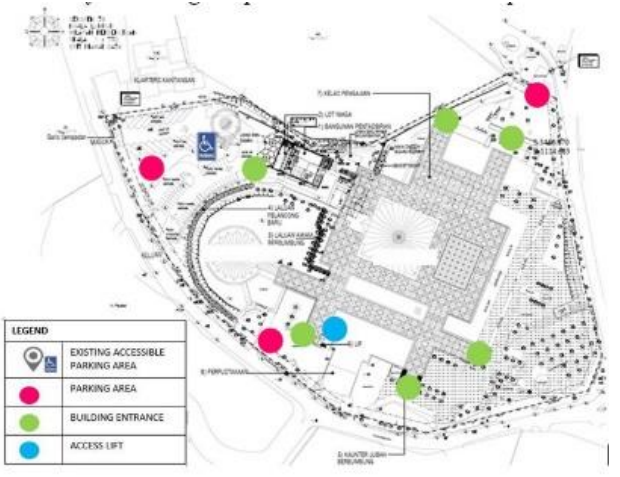

(a)

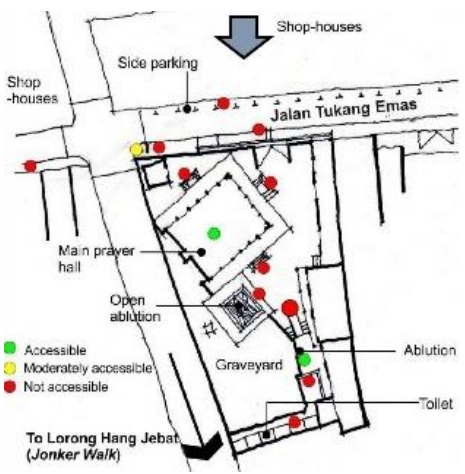

(b)

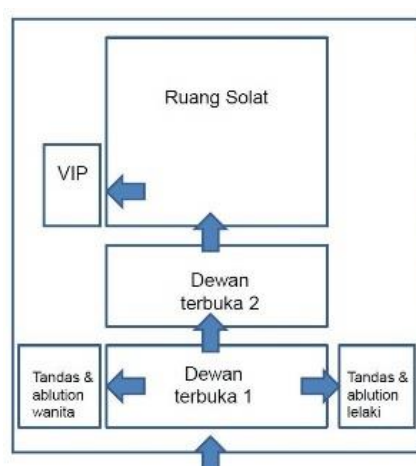

(c)

Fig. 4. (a) Mapping access route of the National Mosque, KL; (b) Sketching access map of Kg. Keling Mosque, Melaka; (c) Diagram of space plan of Kota Kinabalu State Mosque. (Source: Author)

\subsection{Access Audit Checklist, Report and Rating}

The access audit checklist developed from MS1184;2014 (access audit manual \& access audit checklist for buildings, 2018) is used to determine the level of accessibility at each mosque. The checklist has four (4) sections to evaluate the building access, that are, 1) Horizontal Circulation; 2) Vertical Circulation; 3) Supporting Facilities and Amenities and; 4) Additional Facilities and Amenities. Furthermore, this checklist provides scoring to calculate the percentage for Star Rating of Universally Designed mosque. Some snapshots of the checklist and report shows how the level of accessibility is measured, and the data findings to meet the objective of synchronizing all case studies of Mosques to the five (5) common identified access challenges that are i) the entrance, ii) the ablution (wudu') area, iii) the toilet, iv) the prayer hall and v) the path of travel \& wayfinding.

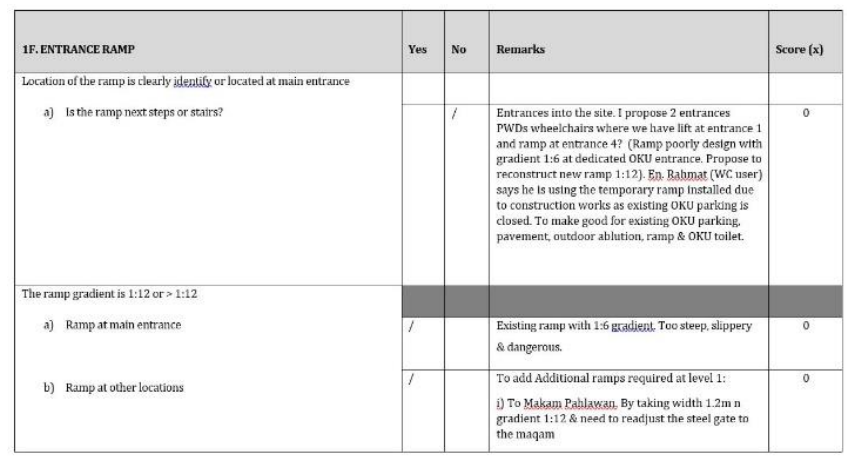

(a)

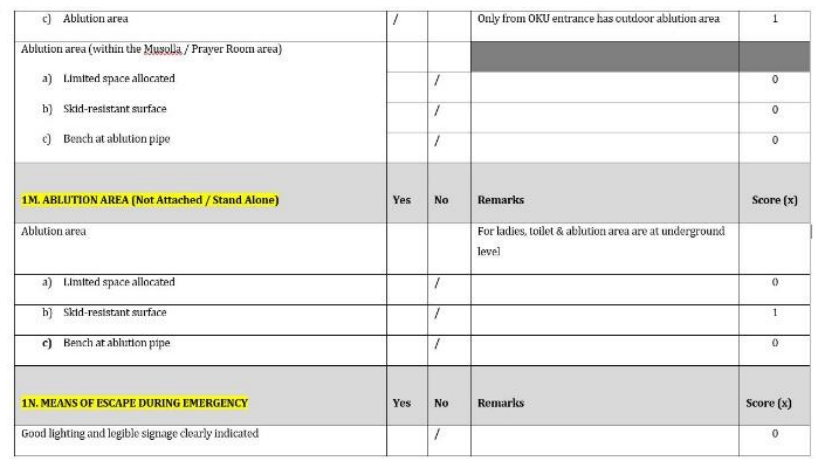

(b) 


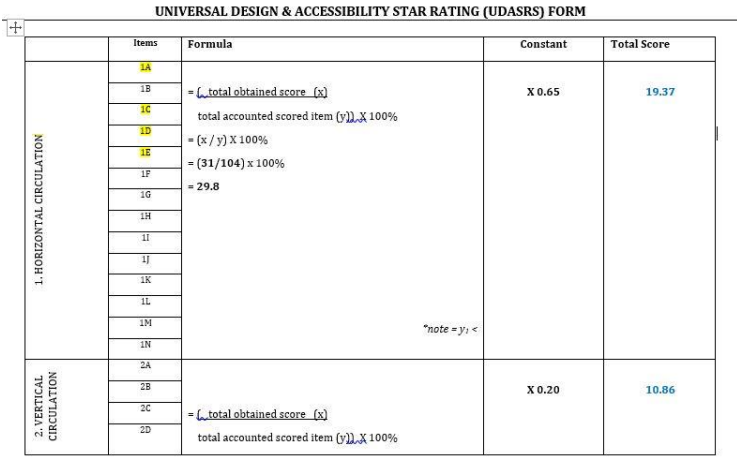

(c)

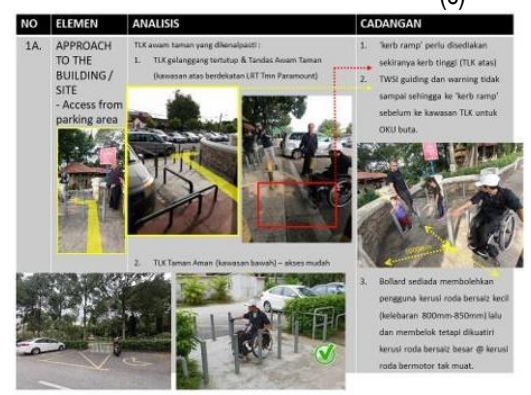

(e)

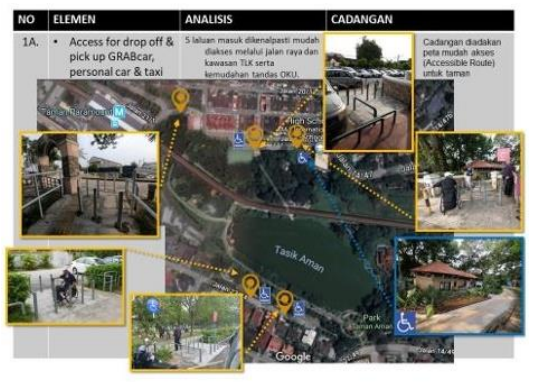

(f)

\begin{tabular}{|c|c|c|c|}
\hline Star Rating & Definition & Score point & d \\
\hline हो & 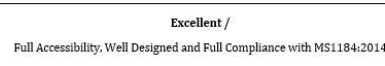 & $81-100 \%$ & \\
\hline & $\begin{array}{c}\text { Good/ } \\
\text { Good Acesssillity and Cood Complance with MS1184:2014 }\end{array}$ & $61-80 \%$ & \\
\hline E & $\begin{array}{c}\text { Satiffactory / } \\
\text { Partially Accessibility and Partially Compliance with MS1184:2014 }\end{array}$ & $41-60 \%$ & \\
\hline$E$ & 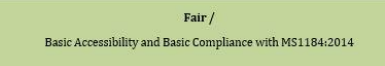 & $21-40 \%$ & $35.35 \%$ \\
\hline (B) & 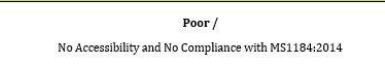 & $0-20 \%$ & \\
\hline
\end{tabular}

(d)

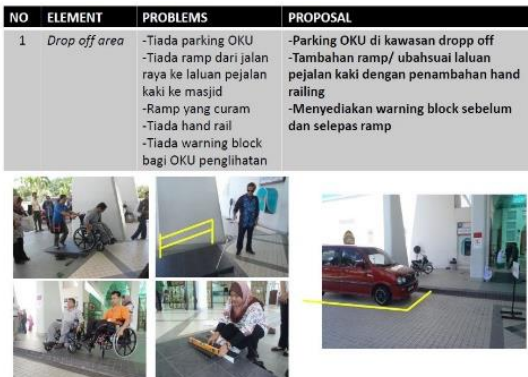

(g)

Fig. 5. (a) Access Audit checklist on common access item; (b) Checklist item on crucial mosque feature; (c) The Universal Design and Star Rating Score calculation form; (d) The Star Rating Assessment percentage score; (e) A page snapshot of the Access Audit report following items in the checklist; (f) An example of the report of proposing an outdoor Accessibility Map for a public park that includes pick-up and drop-off points; (g) A page snapshot of the Access Audit report at a Mosque's drop-off area. (Source: Author)

Table 1. A matrix of the state and heritage Mosques audited in compared to their accessibility level based on the 5 identified common accessibility

\begin{tabular}{|c|c|c|c|c|c|c|c|c|c|c|c|c|c|c|c|c|c|c|c|c|}
\hline \multirow{2}{*}{$\begin{array}{l}\text { State \& Heritage } \\
\text { Mosque }\end{array}$} & \multicolumn{4}{|c|}{ 1)The entrance } & \multicolumn{4}{|c|}{$\begin{array}{l}\text { 2)The ablution (wudu') } \\
\text { area }\end{array}$} & \multicolumn{4}{|c|}{ 3)The toilet } & \multicolumn{4}{|c|}{ 4)The prayer hall } & \multicolumn{4}{|c|}{$\begin{array}{l}\text { 5)The path of travel } \\
\text { (internal) \& Wayfinding }\end{array}$} \\
\hline & Wc & $\mathrm{E} / \mathrm{Pc}$ & $B$ & $\mathrm{D}$ & Wo & $\mathrm{E} / \mathrm{Pc}$ & $B$ & $\mathrm{D}$ & Wc & $\mathrm{E} / \mathrm{Pc}$ & $B$ & $D$ & Wc & $\mathrm{E} / \mathrm{Pc}$ & $B$ & D & Wc & $\mathrm{E} / \mathrm{Pc}$ & $B$ & D \\
\hline $\begin{array}{l}\text { The National Mosque, } \\
\text { Kuala Lumpur }\end{array}$ & $x$ & 1 & $x$ & l & $x$ & 1 & $x$ & 1 & $x$ & 1 & $x$ & 1 & $x$ & 1 & 1 & 1 & $x$ & 1 & $x$ & 1 \\
\hline Kg. Keling Mosque, Melaka & $x$ & 1 & 1 & 1 & $x$ & 1 & 1 & 1 & $x$ & 1 & 1 & 1 & $x$ & 1 & 1 & $x$ & $x$ & $x$ & $x$ & 1 \\
\hline $\begin{array}{l}\text { Kota Kinabalu State } \\
\text { Mosque }\end{array}$ & 1 & 1 & 1 & 1 & 1 & 1 & 1 & 1 & 1 & 1 & 1 & 1 & 1 & 1 & 1 & 1 & 1 & 1 & 1 & 1 \\
\hline $\begin{array}{l}\text { Seremban State Mosque } \\
\qquad E_{\star}^{\star} \star\end{array}$ & $x$ & 1 & 1 & 1 & $x$ & 1 & 1 & 1 & $x$ & 1 & 1 & 1 & $x$ & 1 & 1 & 1 & 1 & 1 & $x$ & 1 \\
\hline $\begin{array}{l}\text { Tuanku Mizan Zainal } \\
\text { Abidin Mosque, Putrajaya } \\
\qquad\end{array}$ & 1 & 1 & 1 & 1 & 1 & 1 & 1 & 1 & 1 & 1 & 1 & 1 & 1 & 1 & 1 & 1 & 1 & 1 & 1 & 1 \\
\hline $\begin{array}{l}\text { Sultan Idris Shah Mosque, } \\
\text { Ipoh }\end{array}$ & $x$ & 1 & 1 & 1 & $x$ & 1 & 1 & 1 & $x$ & 1 & 1 & 1 & $x$ & 1 & I & I & 1 & 1 & $x$ & 1 \\
\hline $\begin{array}{l}\text { Pasir Pekan Mosque, Kota } \\
\text { Bharu }\end{array}$ & $x$ & 1 & 1 & 1 & $x$ & 1 & 1 & 1 & $x$ & 1 & 1 & 1 & $x$ & 1 & 1 & I & 1 & 1 & $x$ & 1 \\
\hline $\begin{array}{l}\text { Sultan Haji Ahmad Shah } \\
\text { Mosque @ IIUM Gombak } \\
\text { Mosque }\end{array}$ & 1 & 1 & 1 & 1 & 1 & 1 & 1 & 1 & I & 1 & 1 & 1 & 1 & 1 & 1 & 1 & 1 & 1 & $x$ & 1 \\
\hline
\end{tabular}

Legend: Wc - Wheelchair User; E/Pc - Elderly / Physically Challenged; B - Blind; D - Deaf. (Source: Author) 
A summary from data analysis, a further access design challenge solution and recommendation are to focus upon the followings:

1. Wayfinding and signage

- $\quad$ To propose five standing accessible maps entrance showing access with international access logo.

- To initiate wayfinding strategies using directional signage, pictogram outside and within corridors, prayer hall, toilets, lift

2. Entrance Ramp Application of interactive Information panel to show the location and access of ablution, toilet, and prayer hall.

- $\quad$ Entrance ramp should be designed according to specification as the ramp can be dangerous if it is too steep.

3. Ablution Area \& Accessible Toilet

- $\quad$ To propose portable ablution stations at ground level and stool for elderly persons

- $\quad$ Providing accessible toilet for PwDs wheelchair users on the ground floor

4. A clear, seamless path of travel and approval of praying on carpeted areas for wheelchair.

- $\quad$ Providing hydraulic lift for old building if necessary.

- $\quad$ For Blind and Deaf persons, it is not mainly the physical access issue, but the communication and visual access issues involve that is lacking.

\subsection{Conclusion}

Conclusively, the five access challenges reviewed in all case study of mosque should be the focus for renovation and upgrading for the mosque management for them to be an inclusive Mosque and claiming to be socially inclusive. Inclusive mosque shall consider all diversity of users for them to visit, performing congregational prayers and socially inclusive for any other Mosque's functions such as a place for meetings, gatherings, educations, celebrations, and even for medical services. Much consideration has still to be taken to attention if accessibility would cover all aspects and all disabilities to be entirely social inclusive mosque environment. These five accessibility design challenges have to be mitigated first either for new mosques' design or mosques, which would like to renovate and upgrade their facilities.

\section{Acknowledgement}

This research paper acknowledges research and consultancy projects as well as Access Audit Workshops in the built environment conducted by KAED Universal Design Unit (KUDU), KAED, IIUM, and lead by Prof. Dato' Sri Ar. Dr. Asiah Abdul Rahim, with the facilitation of the principal author in conducting the access auditing workshop training in Malaysia with funding from various government agencies. The findings and results are throughout ten (10) years of the Access Audit Workshops that focus on the Access Audit of Mosque Building Typology throughout Malaysia.

\section{References}

Access Audit Manual \& Access Audit Checklist for Buildings. (2018). KAED Universal Design Unit, IIUM: Gombak. (Unpublished).

Abdul Kadir, S., \& Jamaludin, M. (2018). Sustainable Life and Social Development through Universally Designed Environment (Vol. 3).

Abdul Kadir, S., Jamaludin, M., \& Rahim Awang, A. (2019). Accessibility Adaptation in Heritage Boutique Hotels: A review on literature. Environment-Behaviour Proceedings Journal, 4. doi:10.21834/e-bpj.v4i10.1633

Asiah, A. R., Azila, A. S., Izawati, T., \& Nur Amirah, A. S. (2015). Masjid for All: Access Audit on Masjid Sultan Idris Shah, Ipoh; Masjid Negeri Seremban; and Masjid Tunku Mizan, Putrajaya.

Asiah, A. R., Naziaty, M. Y., Nur Amirah, A. S., \& Izawati, T. (2015). Universal Design and Social Responsibility: Towards A Sustainable Built Environment. Journal of Universal Design in the Built Environment, 1(1), 5-13.

Asiah, A. R., \& Nur Amirah, A. S. (2014). Universal Design from Islamic Perspective: Malaysian Masjid. Journal of Architecture, Planning \& Construction Management, $4(2)$.

Asiah, A. R., Nur Amirah, A. S., Ismail, S., \& W M Amin, W. S. (2017). Malaysian Plan of Action for People with Disabilities 2016-2022: Way Forward. Paper presented at the UIA 2017 Seoul World Architects Congress, Seoul.

Asif, N., Utaberta, N., \& Sarram, A. (2019). Urban Mosque in the Compact City of Kuala Lumpur: Suitability and Design Considerations. Geographia Technica, 14(Special Issue), 138-147. doi:10.21163/GT_2019.141.27

Creswell, J. W. (2012). Educational Research: Planning, Conducting and Evaluating Quantitative and Qualitative Research (4th Edition ed.): Pearson Education.

Fletcher, V. (2016). Inclusive/universal design: People at the center of the design process. In The Routledge Companion for Architecture Design and Practice: Established and Emerging Trends (pp. 251-268): Taylor and Francis.

Groat, L., \& Wang, D. (2002). Architectural Research Methods. USA: John Wiley \& Sons. 
Hashim, A. E., Samikon, S. A., Ismail, F., Kamarudin, H., Jalil, M. N. M., \& Arrif, N. M. (2012). Access and Accessibility Audit in Commercial Complex: Effectiveness in Respect to People with Disabilities (PWDs). Procedia - Social and Behavioral Sciences, 50, 452-461. doi:http://dx.doi.org/10.1016/j.sbspro.2012.08.049

Heylighen, A., Linden, V. V. d., \& Steenwinkel, I. V. (2017). Ten questions concerning inclusive design of the built environment. Building and Environment, $114,507-517$. doi:https://doi.org/10.1016/j.buildenv.2016.12.008

Hussein, H., \& Yaacob, N. M. (2012). Development of Accessible Design in Malaysia. Procedia - Social and Behavioral Sciences, 68, 121-133. doi:http://dx.doi.org/10.1016/j.sbspro.2012.12.212

Kadir, S. A., \& Jamaludin, M. (2012a). Applicability of Malaysian Standards and Universal Design in Public Buildings in Putrajaya. Procedia - Social and Behavioral Sciences, 36, 659-669. doi:http://dx.doi.org/10.1016/j.sbspro.2012.03.072

Kadir, S. A., \& Jamaludin, M. (2012b). Users' Satisfaction and Perception on Accessibility of Public Buildings in Putrajaya: Access Audit Study. Procedia - Social and Behavioral Sciences, 50, 429-441. doi:http://dx.doi.org/10.1016/j.sbspro.2012.08.047

Kadir, S. A., \& Jamaludin, M. (2013). Universal Design as a Significant Component for Sustainable Life and Social Development. Procedia - Social and Behavioral Sciences, 85, 179-190. doi:http://dx.doi.org/10.1016/j.sbspro.2013.08.349

Kamarudin, H., Ariff, N., wan ismail, w. z., Bakri, A., \& Ithnin, Z. (2014). Malaysian Scenario on Access and Facilities for Persons with Disabilities: A Literature Review (Vol. 15).

Kamarudin, H., Hashim, A. E., Mahmood, M., Ariff, N. R. M., \& Ismail, W. Z. W. (2012). The Implementation of the Malaysian Standard Code of Practice on Access for Disabled Persons by Local Authority. Procedia - Social and Behavioral Sciences, 50, 442-451. doi:http://dx.doi.org/10.1016/j.sbspro.2012.08.048

Kaur, G., \& Tan, P.-L. (2018). Acceptance of Disability: A perspective from people with disability. Asian Journal of Behavioural Studies, 3, 1. doi:10.21834/ajbes.v3i10.75 Kurniawan, H. (2010). Universal Mosque Design. Paper presented at the The 3rd International Conference for Universal Design in HAMAMATSU in 2010, Hamamatsu, Japan.

Mahsa, D. N., Utaberta, N., \& Maulan, S. (2015). Significance of the Application of Universal Design in Mosque Buildings in Malaysia. Applied Mechanics and Materials, 747(2015), 72-75. doi:10.4028/www.scientific.net/AMM.747.72

Maidin, A. J. (2012). Legal Framework Regulating for Improving Accessibility to Built Environment for Disabled Persons in Malaysia.

Merriam, S. B. (2009). Qualitative Research: A Guide to Design and Implementation (2nd Edition ed.): Jossey-Bass

MS2577:2014. (2014). Architecture and asset management of masjid - Code of practice. In: Department of Standards Malaysia.

Nangkula, U., Hafsah, O., Mohd Yazid, M. Y., Nor Atiah, I., \& Sumarni, I. (2015). Issues and Problems of Modern Mosques Design in Malaysia: A Critical Analysis Advances in Environmental Biology, 9(5), 330-337.

Nur Amirah, A. S., Ismail, S., \& Asiah, A. R. (2018a). Planning Accessibility Strategies and Connectivity for Malaysian Urban Built Environment. In G. Craddock, C. Doran L. McNutt, \& D. Rice (Eds.), Transforming our World Through Design, Diversity and Education. Studies in Health Technology and Informatics (Vol. 256). Netherlands: IOS Press.

Nur Amirah, A. S., Ismail, S., \& Asiah, A. R. (2018b). A Review of Universal Design and Accessibility Legislations in Implementation Strategies Among Asian Countries. In Proceeding of The 12th SEATUC Symposium: Engineering Education and Research for Sustainable Development. Yogyakarta, Indonesia.

Nur Amirah, A. S., Ja'afar, N. H., \& Asiah, A. R. (2018). MS1184:2014 Compliance of Basic Accessibility for Persons with Disabilities (PwDs) and Elderly in Traditional Mosque at Melaka Historical Street. In N. A. A. Samad, M. F. Mohamed, \& N. A. Zakaria (Eds.), Prosiding Persidangan Senibina dan Alam Bina Serantau 2018 (SeniBINA2018) 'Tema: Senibina Identiti Kebangsaan', Proceedings of Conference on Regional Architecture and Built Environment 2018 (SeniBINA2018) 'Theme: National Architectural Identity' Pusat Senibina dan Alam Bina Inovatif (SErAMBI), FKAB, UKM.

Shah, S., Shar, B., Khoso, A., Akhund, M. A., \& Soomro, M. (2018). Universal Accessibility: A Tool for Safe, Sustainable and Friendly Environment-A Case Study (Vol. $5)$.

Utaberta, N., Niya, M. D., \& Sabil, A. (2017). Universal Design and Accessibility for People with Disabilities in Masjid Negara, Malaysia. Journal of Islamic Architecture, 4(4). doi:10.18860/jia.v4i4.4499

Walliman, N. (2011). RESEARCH METHODS: THE BASICS. London: Routledge.

Yusof, L. M., \& Jones, D. (2016). The Application of Universal Design Legislation and Standards in Malaysia and Australia. Journal of Universal Design in the Built Environment, 2(1), 17-35

Zainol, H., Mohd Isa, H., Md Sakip, S. R., \& Azmi, A. (2018). Social Sustainable Accessibility for People with Disabilities at Public Transport Stations through Sustainable Development Goals in Malaysia. Environment-Behaviour Proceedings Journal, 3(9), 89. doi:10.21834/e-bpj.v3i9.1499 